\title{
Penerapan Waste Management pada Proyek Konstruksi
}

\author{
I Gusti Putu Adi Suartika Putra \\ Politeknik Negeri Bali \\ Correspondence email: adisuartika@pnb.ac.id
}

\begin{abstract}
Abstrak. Dalam merencanakan dan merealisasikan pembangunan berkelanjutan diperlukan totalitas dari tim proyek, salah satunya dengan menerapkan manajemen sisa bangunan akibat tahap konstruksi dan perusakan bangunan. Manajemen sisa bangunan atau Waste Management penting diperhatikan oleh pelaksana pembangunan (dalam hal ini kontraktor) dimulai pada saat estimasi hingga pelaksanaan di lapangan. Hal ini dilakukan agar limbah yang dihasilkan dapat seminimal mungkin dan tentunya berpengaruh pada efisiensi penggunaan material dan biaya yang akan dikeluarkan untuk pengadaan material maupun pengelolaan dan pengolahan limbahnya. Tujuan penelitian ini adalah untuk mengetahui faktor-faktor yang perlu diperhatikan dalam penerapan waste management pada proyek konstruksi dan penanganan sisa material konstruksi dari proses pembangunan. Pada pelaksanaannya pengambilan data dilakukan dengan penyebaran kuisioner di lapangan kepada 40 project manager dan pengamatan di lapangan yang dibatasi pada pekerjaan pemotongan besi untuk penulangan kolom, balok dan plat lantai serta pengecoran. Pengamatan masing-masing dicari 15 data pengamatan yang mewakili. Perhitungan kuisioner menggunakan analisis deskriptif sedangkan untuk mendapatkan sisa material pemotongan besi dan pengecoran digunakan perhitungan sederhana. Dari hasil penyebaran kuisioner diketahui bahwa klasifikasi peringkat tertinggi dalam penerapan waste management pada proyek konstruksi adalah reduce (pelatihan kepada pekerja dalam penggunaan peralatan seefisien mungkin).
\end{abstract}

Kata Kunci: waste management; persentase; reuse; proyek konstruksi

\section{PENDAHULUAN}

Permasalahan utama lingkungan yang diduga memberikan kontribusi dalam perusakan lingkungan adalah: pencemaran udara; pencemaran air; produksi limbah; penurunan ketersediaan pangan dan penurunan keanekaragaman hayati. Pada prinsipnya pembangunan berbagai infrastruktur harus didasarkan pada teknologi bangunan lokal dan tuntutan ekologis alam. Salah satunya penggunaan material untuk konstruksi.

Saat ini di Indonesia banyak kontraktor yang mulai mengedepankan konsep green construction/ green building. Penerapan konsep green building dapat dilakukan dalam berbagai unsur mulai dari bahan bangunan, desain, sampai perawatan bangunan dengan memanfaatkan teknologi canggih. Konstribusi industri konstruksi dalam perwujudannya memiliki andil dan manfaatnya yang sangat besar bagi pembangunan. Hal ini dapat ditunjukkan dari peran serta industri konstruksi dalam menerapkan sustainable construction pada penggunaan material, metode kerja/pelaksanaan di lapangan, penyelesaian arsitektural dan interior.

Dalam merencanakan dan merealisasikan pembangunan berkelanjutan diperlukan totalitas dari tim proyek, salah satunya dengan menerapkan manajemen sisa bangunan akibat tahap konstruksi dan perusakan bangunan. Manajemen sisa bangunan atau Waste Management penting diperhatikan oleh pelaksana pembangunan (dalam hal ini kontraktor) dimulai pada saat estimasi hingga pelaksanaan di lapangan. Hal ini dilakukan agar sisa material dapat seminimal mungkin dihasilkan sehingga tidak banyak terjadi penumpukan sisa material di lokasi proyek dan tentunya dapat menghemat biaya. Bagaimana mengelola material yang akan digunakan agar dapat seefektif mungkin penggunaannya? Dari beberapa penelitian menyatakan bahwa biaya material menyerap $50-70 \%$ dari biaya proyek, biaya ini belum termasuk biaya penyimpanan material. Oleh karena itu penggunaan teknik manajemen yang baik dan tepat untuk membeli, menyimpan, mendistribusikan, dan menghitung material konstruksi menjadi sangat penting (Ervianto, 2004).

Dari paparan tersebut di atas, penulis mencoba melakukan penelitian mengenai penerapan waste management pada proyek konstruksi agar limbah yang dihasilkan dapat seminimal mungkin. Hal ini berpengaruh tentunya pada efisiensi penggunaan material dan biaya yang akan dikeluarkan untuk pengadaan material maupun pengelolaan dan pengolahan limbahnya. Tujuan dari penelitian ini adalah untuk mengetahui faktor-faktor yang perlu diperhatikan dalam penerapan waste management pada proyek konstruksi.

\section{METODE}

Penelitian ini dilakukan dengan cara survei yang menggunakan kuesioner dan juga pengamatan di lapangan secara langsung. Responden yang menjadi sasaran dalam penyebaran kuesioner adalah para Project Manager dengan pengalaman kerja minimal 3 tahun, dari sejumlah kontraktor skala besar yang menangani proyek senilai tidak kurang dari Rp. 5.000.000.000,-. di Kabupaten Badung dan Kota Denpasar. Jumlah responden pada penelitian ini adalah sebanyak 40 sampel. Penelitian ini dilakukan pada penerapan waste management dalam proyek konstruksi gedung bertingkat yang menyangkut jenis penerapan waste management yang dilakukan untuk menangani sisa material. 
Adapun metoda perhitungan yang akan digunakan untuk menganalisa data hasil pengisian kuisioner oleh responden adalah sebagai berikut :

\section{Metode Statistik Nilai Rata-Rata (Mean)}

$x=\frac{1}{n} \sum_{i=1}^{n} x i$

Menganalisis nilai mean dari skor skala jawaban butir-butir tertentu pada kuisioner yang telah diisi responden. Berfungsi sebagai data pelengkap data primer.

\section{Metode Statistik Standar Deviasi}

$S D=\sqrt{\frac{\sum(x i-x)^{2}}{n-1}}$

Metoda ini digunakan apabila ada data yang mempunyai nilai mean yang sama.

Setelah melakukan penghitungan di atas kemudian dilakukan pengelompokkan jenis penanganan sisa material konstruksi yang meliputi reduce, reuse, recycle dan salvage. Kemudian dicari nilai rata-rata (mean) per klasifikasi pengelompokkan berikut peringkatnya sesuai pengelompokkan jenis penanganan sisa material konstruksi.

\section{HASIL DAN PEMBAHASAN}

Untuk mengetahui faktor-faktor yang perlu diperhatikan dalam Penerapan Waste Management pada Proyek Konstruksi, dari keseluruhan pernyataan kuisioner yang diperoleh dibuat analisis seperti pada tabel berikut ini.

Tabel 1. Peringkat Faktor-Faktor yang perlu Diperhatikan dalam Penerapan Waste Management pada Proyek Konstruksi

\begin{tabular}{clccc}
\hline No & \multicolumn{1}{c}{ Klasifikasi } & Mean & SD & Ranking \\
\hline 1 & Reduce & 4,30 & 1,36 & 2 \\
2 & Reuse & 4,19 & 0,81 & 3 \\
3 & Recycle & 3,98 & 0,71 & 4 \\
4 & Salvage & 3,68 & 1,06 & 4 \\
\hline
\end{tabular}

Sumber: Data Olahan (2020)

Tabel 2. Peringkat Faktor-Faktor yang perlu Diperhatikan dalam Penerapan Waste Management pada Proyek Konstruksi (Reduce)

\begin{tabular}{|c|c|c|c|c|}
\hline No & Pernyataan & Mean & SD & Ranking \\
\hline 1 & Pelatihan kepada pekerja dalam penggunaan peralatan seefisien mungkin. & 4,65 & 0,53 & 1 \\
\hline 2 & Optimalisasi penggunaan material. & 4,63 & 0,49 & 2 \\
\hline 3 & Penerapan metoda konstruksi yang efesien. & 4,53 & 0,55 & 3 \\
\hline 4 & Tempat penyimpanan material yang tahan terhadap cuaca. & 4,50 & 0,55 & 4 \\
\hline 5 & Pengontrolan ketepatan jumlah material yang dikirim ke proyek. & 4,48 & 0,67 & 5 \\
\hline 6 & Komunikasi dalam rapat untuk usaha mengurangi sisa material. & 4,45 & 0,55 & 6 \\
\hline 7 & $\begin{array}{l}\text { Pencatatan material yang dapat digunakan kembali, dapat didaur ulang atau } \\
\text { menjadi sisa sampah. }\end{array}$ & 4,45 & 0,6 & 7 \\
\hline 8 & Akurasi identifikasi material. & 4,43 & 0,55 & 8 \\
\hline 9 & Estimasi tipe dan kuantitas sisa material yang akan dihasilkan. & 4,4 & 0,66 & 9 \\
\hline 10 & Pengaturan letak dan tumpukan material di tempat penyimpanan. & 4,35 & 0,62 & 10 \\
\hline 11 & $\begin{array}{l}\text { Penggunaan alternatif bahan bakar ramah lingkungan sebagai pengganti diesel } \\
\text { atau solar pada saat transportasi material. }\end{array}$ & 4,3 & 0,65 & 11 \\
\hline 12 & Peningkatan akurasi estimasi dan pemesanan. & 4,28 & 0,51 & 12 \\
\hline 13 & Pengaturan jadwal pengiriman material. & 4,25 & 0,71 & 13 \\
\hline 14 & Daftar referensi supplier dan pihak pendaur ulang. & 4,15 & 0,62 & 14 \\
\hline 15 & Kerjasama dengan supplier untuk membeli kelebihan material. & 4,08 & 0,73 & 15 \\
\hline 16 & Jarak pemindahan/perjalanan dari raw material menuju lokasi proyek. & 4,05 & 0,75 & 16 \\
\hline 17 & Pengefisienan kemasan. & 4,03 & 0,83 & 17 \\
\hline 18 & Penyediaan area pemotongan material. & 3,98 & 0,77 & 18 \\
\hline 19 & Pemilihan material dengan kemasan minimal atau tanpa kemasan. & 3,65 & 0,86 & 19 \\
\hline
\end{tabular}

Sumber: Data Olahan (2020) 
Dari data di atas dapat diketahui bahwa peringkat pertama pada pernyataan pelatihan kepada pekerja dalam penggunaan peralatan seefisien mungkin. Pelatihan kepada pekerja dalam penggunaan peralatan seefisien mungkin memberikan kontribusi yang cukup besar dalam mengurangi waste dan budget pada pelaksanaan proyek konstruksi (di lapangan), peringkat berikutnya adalah optimalisasi penggunaan material. Optimalisasi penggunaan material penting untuk mendapatkan perhatian pada saat perencanaan dan ketika pelaksanaan langsung di lapangan sampai pada pengawasan penggunaan material sehingga dapat mengurangi besarnya waste yang terbuang menjadi limbah.

Tabel 3. Peringkat Faktor-Faktor yang perlu Diperhatikan dalam Penerapan Waste Management pada Proyek Konstruksi (Reuse)

\begin{tabular}{clccc}
\hline No & \multicolumn{1}{c}{ Pernyataan } & Mean & SD & Ranking \\
\hline 1 & Pemanfaatan sisa material yang salvageable. & 4,43 & 0,59 & 1 \\
2 & Pemanfaatan material dekonstruksi & 4,15 & 0,80 & 2 \\
3 & Pengalokasian untuk proyek mendatang. & 4,00 & 1,04 & 3 \\
\hline
\end{tabular}

Sumber: Data Olahan (2020)

Dari data di atas dapat diketahui bahwa peringkat pertama dari faktor-faktor yang perlu diperhatikan mengenai penerapan waste management (reuse) pada proyek konstruksi adalah pemanfaatan sisa material yang salvageable dengan nilai mean 4,43 dan standar deviasi 0,59. pemanfaatan sisa material yang masih bisa digunakan kembali dapat mengoptimalkan penggunaan material pada proyek konstruksi. Misalnya saja sisa material besi pekerjaan kolom dapat digunakan kembali untuk pembuatan stek atau yang lainnya sehingga dapat bermanfaat dan mengurangi limbah.

Tabel 4. Peringkat Faktor-Faktor yang perlu Diperhatikan dalam Penerapan Waste Management pada Proyek Konstruksi (Recycle).

\begin{tabular}{clccc}
\hline No & Pernyataan & Mean & SD & Ranking \\
\hline 1 & Upcycle, meningkatkan nilai jika dibandingkan dengan produksi sebelumnya & 4,28 & 0,6 & 1 \\
2 & Recycle, bernilai sama jika dibandingkan dengan produksi sebelumnya & 3,95 & 0,64 \\
3 & Downcycle, menurunkan nilai jika dibandingkan dengan produksi sebelumnya. & 3,7 & 2 \\
\hline
\end{tabular}

Sumber: Data Olahan (2020)

Dari data di atas dapat diketahui bahwa peringkat pertama dari faktor-faktor yang perlu diperhatikan mengenai penerapan waste management (recycle) pada proyek konstruksi adalah upcycle, meningkatkan nilai jika dibandingkan dengan produksi sebelumnya dengan nilai mean 4,28 dan standar deviasi 0,6. Upcycle dimaksudkan untuk mengolah kembali material menjadi suatu produk baru yang berguna dan masih memiliki nilai jual.

Tabel 5. Peringkat Faktor-Faktor yang perlu Diperhatikan dalam Penerapan Waste Management pada Proyek Konstruksi (Salvage)

\begin{tabular}{clccc}
\hline No & \multicolumn{1}{c}{ Pernyataan } & Mean & SD & Ranking \\
\hline 1 & Pemindahan sisa material yang bernilai oleh salvage company. & 4,15 & 0,74 & 1 \\
2 & Sisa material disumbangkan kepada organisasi amal. & 3,65 & 1,14 & 2 \\
3 & Pekerja diizinkan mengambil sisa material yang salvageable. & 3,23 & 1,29 & 3 \\
\hline
\end{tabular}

Sumber: Data Olahan (2020)

Dari data di atas dapat diketahui bahwa:

Ranking pertama dari faktor-faktor yang perlu diperhatikan mengenai penerapan waste management (salvage) pada proyek konstruksi adalah pemindahan sisa material yang bernilai oleh salvage company dengan nilai mean 4,15 dan standar deviasi 0,74. Pemindahan sisa material yang bernilai oleh salvage company dimaksudkan untuk mengolah kembali sisa material oleh pihak ketiga menjadi barang yang bermanfaat.

\section{Pembahasan}

Construction Waste adalah sampah yang berupa sisa material konstruksi dan sampah lainnya yang berasal dari aktivitas selama pelaksanaan konstruksi, pembongkaran dan pembersihan lahan pada awal pelaksanaan proyek. Sisa material konstruksi yang terjadi pada aktivitas konstruksi dan pembongkaran diantaranya metal, kaca, beton, pasir, batu, keramik, cat, gypsum dan kayu, sedangkan sampah konstruksi yang timbul dari aktivitas pembersihan lahan berupa batu, tanah dan pepohonan yang ditebang. Construction waste dapat digolongkan ke dalam dua kategori berdasarkan penyebabnya yaitu indirect waste dan direct waste. Indirect waste adalah sisa material yang terjadi dalam bentuk pemborosan (moneter loss) akibat kelebihan pemakaian volume material dari yang direncanakan dan tidak terlihat sebagai sampah di lapangan. Direct waste adalah sisa material yang timbul di proyek karena rusak dan tidak dapat diperbaiki dan digunakan kembali selama proses konstruksi (Skoyles, 1976).

Manajemen sisa akibat kegiatan kostruksi dan pembongkaran bangunan bertujuan untuk mengurangi pemanfaatan berbagai sumber material bangunan, memakai kembali dan mendaur ulang. Mengurangi pemanfaatan 
sumber material bangunan berkaitan erat dengan pembangunan proyek baru dan proyek yang sedang melakukan renovasi yang cukup besar yang menyangkut pengurangan limbah pada proses pemesanan material, proses rekayasa nilai pada disain bangunan dan komponennya. Pada proses renovasi dan pembongkaran bangunan, komponen bangunan mempunyai nilai yang memungkinkan untuk digunakan kembali pada proyek tersebut, disimpan dan digunakan pada proyek lain, atau dijual untuk tetap digunakan sesuai dengan fungsinya. Daur ulang material bangunan dapat dimanfaatkan manakala jumlah yang tersedia cukup dan adanya permintaan pasar. Pada prinsipnya, sisa hasil konstruksi dan biaya yang ditimbulkannya harus dikelola seperti sumberdaya lain dalam proyek konstruksi dengan mempertimbangkan pengaruhnya terhadap lingkungan, tanah, dan sumber air (Ervianto, 2010).

Hasil penelitian menunjukkan peringkat pertama dari empat pengelompokkan (klasifikasi) mengenai penerapan waste management pada proyek konstruksi adalah reduce dengan nilai mean 4,30. Ranking selanjutnya adalah reuse, recycle dan salvage dengan nilai mean 4,19, 3,98 dan 3,68. Sehingga diharapkan upaya untuk mengurangi/meminimalkan sisa material dilakukan dengan tindakan pencegahan yang mencangkup optimalisasi penggunaan material, penerapan metode konstruksi yang efektif dan efisien.

\section{SIMPULAN}

Untuk hasil data kuisioner dari 40 responden dapat ditarik kesimpulan, untuk klasifikasi peringkat tertinggi beserta tiga (3) peringkat tertinggi untuk masing-masing klasifikasi dari faktor-faktor yang perlu diperhatikan dalam penerapan waste management pada proyek konstruksi yaitu :

a. Reduce

1. Pelatihan kepada pekerja dalam penggunaan peralatan seefisien mungkin.

2. Optimalisasi penggunaan material.

3. Penerapan metoda konstruksi yang efesien.

b. Reuse

1. Pemanfaatan sisa material yang salvageable.

2. Pemanfaatan material dekonstruksi.

3. Pengalokasian untuk proyek mendatang.

c. Recycle

1. Upcycle, meningkatkan nilai jika dibandingkan dengan produksi sebelumnya.

2. Recycle, bernilai sama jika dibandingkan dengan produksi sebelumnya.

3. Downcycle, menurunkan nilai jika dibandingkan dengan produksi sebelumnya.

d. Salvage

1. Pemindahan sisa material yang bernilai oleh salvage company.

2. Sisa material disumbangkan kepada organisasi amal.

3. Pekerja diizinkan mengambil sisa material yang salvageable.

\section{DAFTAR PUSTAKA}

Ervianto. (2010). Implementasi Pembangunan Berkelanjutan Tinjauan Pada Tahap Konstruksi, Seminar Konferensi Teknik Sipil IV-2010, Universitas Udayana Bali, 2-3 Juni 2010.

Ervianto. (2010). Studi Penerapan Konsep Green Building Pada Industri Jasa Konstruksi, Prosiding Seminar Nasional Teknik Sipil VI-2010, Institut Teknologi Sepuluh November, Surabaya, 27 Januari 2010.

Ervianto. (2004). Teori - Aplikasi Manajemen Proyek Konstruksi, Penerbit Andi, Yogyakarta.

Skoyles, E.F., Material wastage: A misuse of resources, Building Research and Practice, July/April 1976. 